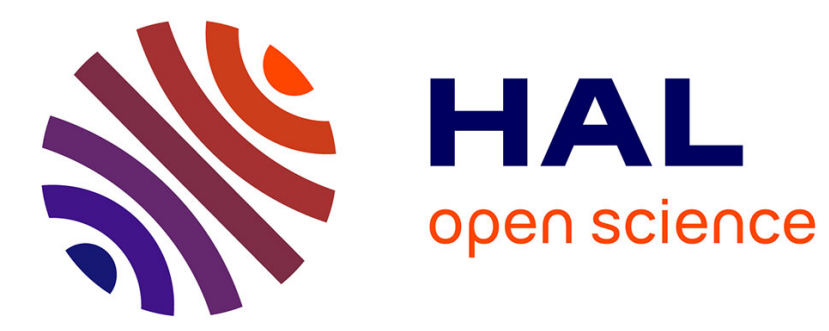

\title{
Tethysbaena ledoyeri n. sp., a new thermosbaenacean species (Thermosbaenacea) from the Port-Miou karstic aquifer in southern France
}

H. p. Wagner, P. Chevaldonne

\section{- To cite this version:}

H. p. Wagner, P. Chevaldonne. Tethysbaena ledoyeri n. sp., a new thermosbaenacean species (Thermosbaenacea) from the Port-Miou karstic aquifer in southern France. Crustaceana, 2020, 93 (7), pp.819-841. 10.1163/15685403-bja10068 . hal-02947697

\section{HAL Id: hal-02947697 \\ https://hal-amu.archives-ouvertes.fr/hal-02947697}

Submitted on 5 Oct 2020

HAL is a multi-disciplinary open access archive for the deposit and dissemination of scientific research documents, whether they are published or not. The documents may come from teaching and research institutions in France or abroad, or from public or private research centers.
L'archive ouverte pluridisciplinaire HAL, est destinée au dépôt et à la diffusion de documents scientifiques de niveau recherche, publiés ou non, émanant des établissements d'enseignement et de recherche français ou étrangers, des laboratoires publics ou privés. 
H. P. Wagner \& P. Chevaldonné

Tethysbaena ledoyeri nov.

Tethysbaena ledoyeri n. sp., a new thermosbaenacean species (Thermosbaenacea) from the Port-Miou karstic aquifer in southern France

by

H. P. Wagner ${ }^{1,3}$ ) and P. Chevaldonné ${ }^{2,4}$ )

1) Platanenrode 6, NL-2317 BT Leiden, The Netherlands

${ }^{2}$ ) IMBE, CNRS, IRD, Aix Marseille Université, Avignon Université, Station Marine d'Endoume, Rue la Batterie des Lions, F-13007 Marseille, France

\section{ABSTRACT}

A new species of the thermosbaenacean genus Tethysbaena Wagner,1994 is described as T. ledoyeri n. sp.

Together with an as yet undescribed amphipod (Niphargus sp.) it is an inhabitant of the brackish water of an aquifer that flows through the Basse-Provence Urgonian karstic system and reaches the Mediterranean Sea, $15 \mathrm{~km}$ east of Marseille, in the "Calanques" coast. The new taxon, being part of the T. argentarii-group, is compared with its closest allies in this group. Preliminary DNA data obtained from two specimens of the new species provide confirmation of its close ties to T. argentarii but also to T. scabra, the two geographically

\footnotetext{
${ }^{3}$ ) Co-corresponding author; e-mail: drhpwagner@hotmail.com

$\left.{ }^{4}\right)$ Co-corresponding author; e-mail: pierre.chevaldonne@imbe.fr
} 
closest described species.

\section{RÉSUMÉ}

Une nouvelle espèce de Thermosbaenacea du genre Tethysbaena Wagner, 1994 est décrite : T. ledoyeri n. sp.

Avec une espèce encore non décrite d'amphipode (Niphargus sp.), cette espèce habite les eaux saumâtres d'un aquifère qui s'écoule dans le système karstique Urgonien de la Basse Provence avant d'atteindre la mer Méditerranée à $15 \mathrm{~km}$ de Marseille, sur la côte des "Calanques". Le nouveau taxon fait partie du "groupe T. argentarii" et il est comparé ici aux espèces les plus proches dans ce groupe. Des données ADN préliminaires obtenues sur deux spécimens de la nouvelle espèce permettent de confirmer ses relations étroites avec $T$. argentarii mais aussi avec T. scabra, les deux espèces décrites géographiquement les plus proches.

\section{INTRODUCTION}

Underground river systems are among the most difficult places to access on Earth, and they are also highly difficult to colonize by life forms, due to remoteness and the scarcity of food. Among the life forms able to live in such environments are several groups of crustaceans, including the Thermosbaenacea, a peracarid order that is exclusively troglobitic, anchialine and/or interstitial (Jaume, 2008).

In June 1993 Marc Douchet and a team of speleo-divers conducted a diving exploration upstream of the dam that was built in the Port-Miou aquifer, located near Marseille, France. During one of the dives a specimen of a thermosbaenacean was caught with a simple jar at $330 \mathrm{~m}$ upstream of the dam (= ca. $850 \mathrm{~m}$ from the sea) at a depth of $30 \mathrm{~m}$, although the divers observed numerous individuals. The specimen, an incomplete female, was given to Dr Michel 
Ledoyer for study, who submitted the specimen in the autumn of 1994 to the senior author (HPW) as it appeared to be a new species of the then recently described genus Tethysbaena Wagner, 1994.

However it lasted until August 2003 until the junior author (PC) collected 27 specimens of this new taxon at a nearby sampling site during two diving explorations of the same aquifer at Port-Miou. Some specimens were damaged, others were lost, but in the sample from dive PL166, which included 15 specimens, only female specimens were represented and we decided to wait with a description of this material until male specimens were collected, too. Finally, during a dive at the same location on 14 October 2019 two males, among 12 specimens, were captured and kept in the laboratory for a while. A part of this material was examined for the description of the new taxon and two specimens (from dives PL163 and PL715) were used for a DNA analysis.

Although the new taxon shows resemblance to the other species of the "T. argentarii species-group" described so far, the present species presents distinct features that clearly warrant establishing a new species. Furthermore, it is found in a karstic aquifer that is geographically isolated from those of the other species of the group.

\section{ECOLOGY AND HISTORY OF EXPLORATION}

The karstic aquifer of Port-Miou (fig. 1) is an underground river with a marine outlet opening entirely under the sea surface, at a depth of 2 to $12 \mathrm{~m}$ (the size of the outlet into the sea). The river flows from north to south, almost exactly, through a gallery section of 16-22.5 $\mathrm{m}$ in diameter, i.e., a surface area of $200-400 \mathrm{~m}^{2}$ (Lombard, 1977; Anonymous, 1978). The river has been explored by speleo-divers up to $2 \mathrm{~km}$ from the entrance, where a vertical siphon leads down to the current record depth of $233 \mathrm{~m}$, and from there, a horizontal gallery continues further north (Méniscus, 2017). 
The river discharge has been estimated to range from 1 to $100 \mathrm{~m}^{3} / \mathrm{s}$ (average $7 \mathrm{~m}^{3} / \mathrm{s}$ ), creating a counter-current of seawater entering the gallery from the sea, and the water is always brackish (Lombard, 1977; Anonymous, 1978). Even in the terminal well at the depth of $147 \mathrm{~m}$, speleo-diver Marc Douchet collected water with a salinity measured at $6.6 \mathrm{~g} / \mathrm{l}$ (Fage, 1993). Then, a halocline was found at $223 \mathrm{~m}$, with water below that being even more haline (Méniscus, 2017; Arfib et al., 2018). Little is known about the catchment area of this river, but it is quite large $\left(>1000 \mathrm{~km}^{2}\right)$ and includes, to the north, the area of the Beausset Basin, Mts. Ste Baume and Ste-Victoire (Gilli, 2001).

In the 1970's, a joint venture began the construction of an underground, underwater dam on the river, at the level of a large natural air chamber located $530 \mathrm{~m}$ from the sea (fig. 1), in an attempt to stop the seawater intrusion up the river and to obtain water suitable for drinking purposes. The water depth at this level was ca. 15-20 m. In 1972-73, time-series of measurements indicated that salinity varied from 1.5 to $20 \mathrm{~g} / 1$ (average $6-12 \mathrm{~g} / 1$ depending on the depth), the lowest values being in February-March, the highest in the summer; current speeds were recorded to vary from 15 to $110 \mathrm{~cm} / \mathrm{s}$, the highest values being reached during winter (Lombard \& Potié, 1980). After the completion of the dam in 1977, the salinity of the water upstream of the dam decreased but remained brackish (Anonymous, 1978; Potié, 1979), so exploitation of the dam was discontinued. Today, the dam is still in place and water is allowed to run down through 4 pipes of 1 to $0.5 \mathrm{~m}$ diameter. During floods, water is allowed to flow over the top of the dam designed as a spillway. Today, the direct intrusion of seawater from the entrance is very limited upstream of the dam, but the salinity indicates that seawater penetrates elsewhere, possibly through a deeper network. The water temperature is reported to be rather constant year round, i.e., around $15-17^{\circ} \mathrm{C}$, with extremes in the range of $11-20^{\circ} \mathrm{C}$ (Cavalera 2007).

Few biological observations exist for Port-Miou, and those are almost all limited to the 
first $50 \mathrm{~m}$, near the entrance of the gallery in the marine part. There, the community reflects that of semi-dark caves common in the area (Corroy et al., 1958). Personal observations (PC) made since 1987 in the first $100 \mathrm{~m}$ of the gallery corroborate previous findings but also point out the peculiar "estuarine" biological component related to the salt-water wedge and the strong currents of opposite direction between the two water masses (mussels, Mytilus galloprovincialis Lamarck, 1819, oysters, Ostrea edulis Linnaeus, 1758, but also many large filter-feeder invertebrates usually absent from caves: large hydroids, ascidians, crinoids, brittle-stars, sabellid polychaetes, and a few large specimens of the bivalve mollusc Pinna nobilis Linnaeus, 1758). The only rare observations from deeper parts within the gallery are those from the 1964 and 1968 expeditions (Martin, 1968; Vernette, 1968). It was then noticed that mussels could be found alive up to $740 \mathrm{~m}$ from the entrance, that is $200 \mathrm{~m}$ upstream of today's dam. Pinna nobilis were reported from up to $300 \mathrm{~m}$ from the entrance. Even more interesting, but enigmatic, a large white crab was spotted at $650 \mathrm{~m}$ from the entrance, and a white or light pink, large-headed, eel-like fish was reported by both expeditions, at 300 and $700 \mathrm{~m}$ from the entrance.

The absence of mussels at these levels today, could easily be explained by the construction of the dam. If the water upstream of the dam is still brackish, probably because of various sources of seawater infiltration through small cracks and fissures in the karst, the dam did, however, efficiently block most of the inflow of seawater from the entrance, and therefore the possibility for larvae of marine colonizers to significantly go further upstream of the dam and settle.

Finally, the 1993 Marc Douchet expedition observed and sampled the thermosbaenacean species here described from a secondary gallery with low water circulation, $300-330 \mathrm{~m}$ upstream (fig. 1) of the dam (Schmit, 1993; M. Douchet, pers. comm.). Attempts to capture more specimens in March 1994 at the same location failed. 
In August 2003, the $120 \mathrm{~m}$ explored upstream of the dam by one of us (PC) appeared devoid of any sessile organism on the walls, rocks, or sediment. Specimens of the thermosbaenacean could be captured using a suction bottle at depths ranging from 15 to $23 \mathrm{~m}$, near the dam, as well as $120 \mathrm{~m}$ upstream of it (fig. 1). Together with thermosbaenaceans, 5 specimens of a new species of the amphipod genus Niphargus were captured immediately near the dam, where they swam actively over the bottom. No other life form could be seen in this environment, although one sample recovered a copepod exoskeleton (ecdysium). During these 2003 dives, temperature at the level of the dam and $120 \mathrm{~m}$ upstream was homogeneous from the surface to $23 \mathrm{~m}$ depth, and was measured at $17^{\circ} \mathrm{C}$. Salinity reached $11 \mathrm{~g} / \mathrm{l}$, except in the top $5 \mathrm{~m}$ where it was lower but still brackish.

In April 2019, 3 dives were conducted in the same area as in 2003, but only a few rare Niphargus could be seen and no thermosbaenaceans, despite intensive search. However, 6 months later in October 2019, one dive at the same station yielded 12 specimens of the new Tethysbaena. In that period, temperature was recorded at $18^{\circ} \mathrm{C}$ and salinity at $11 \mathrm{~g} / \mathrm{L}$.

\section{MATERIAL AND METHODS}

The material examined with the aid of a compound microscope was coloured first by a cuticular staining of $0.05 \%$ Chlorazol Black B, dissolved in lactic acid, as described by Wagner (1994). Then dissection was done in lactic acid and mounting was done on slides and sealed in Berlese's fluid. Slides were observed with a camera lucida at resolutions up to $1000 \times$. The terminology follows Wagner (1994).

All specimens examined in this study were collected by using a suction bottle operated by divers (Chevaldonné et al., 2008), except for the specimen of 1993, directly captured with a jar. They were maintained alive at a temperature of $15-17^{\circ} \mathrm{C}$ before being stored in $95 \%$ ethanol. 
The holotype $(\circlearrowleft)$, allotype $(+$ ) and all three paratypes $(3+$ 우) have been deposited in the collection of Naturalis (the former Nationaal Natuurhistorisch Museum) Leiden, The Netherlands $(\mathrm{RMNH})$ and the remaining paratypes are deposited in the reference collection at the Station Marine d'Endoume (IMBE) at Marseille, France.

Two whole specimens have been used to extract DNA for molecular studies. One from dive PL163 in August 2003 (sample Tled163-1) and one from dive PL715 in October 2019 (sample Tled715-1). In order to obtain DNA barcodes of the new species, total genomic DNA was extracted as in Chevaldonné et al. (2015). A fragment (531 to 669 base pairs) of the mitochondrial gene coding for cytochrome c oxidase subunit I (COI) could be amplified for both specimens, while only Tled715-1 could be amplified (996 base pairs) for the nuclear gene of the small subunit ribosomal RNA (18S). Classical polymerase chain reaction (PCR) protocols were used, as in Chevaldonné et al. (2015). The three sequences obtained have been deposited at the ENA-EMBL database (accession \# MT765074, MT765075 and MT765174). Sequence alignment and editing were conducted with BIOEDIT v7.0.9 (Hall, 1999), phylogenetic reconstructions were estimated using the Neighbour-Joining and MaximumLikelihood methods, both with bootstrapping support assessment over 1000 replicates in CLUSTALX 2.1 (Larkin et al., 2007) and PHYML 3.0 (Guindon et al., 2010; Lefort et al., 2017), respectively.

SYSTEMATICS

Tethysbaena ledoyeri n. sp. (figs. 2-16)

Tethysbaena sp. nov.; Chevaldonné et al., 2005, 2008. 
Material examined.- Holotype: $1 \hat{\jmath}$, body length $2.7 \mathrm{~mm}$, dive PL715, Port-Miou karstic aquifer, 50-100 m upstream from the dam, depth 20-23 m, Port-Miou, France, 14 October 2019, coll. P. Chevaldonné, 14 October 2019, RMNH.CRUS.G.127 (former SME Tled715-8). Allotype: 1 o, body length $3.7 \mathrm{~mm}$, sampling data as in holotype, RMNH.CRUS.G.128 (former Tled715-4). Paratypes: 4 우 (body length 1.9-3.5 mm), 1 (body length $3.4 \mathrm{~mm}$ ), sampling data as in holotype, Station Marine d'Endoume (SME) collection numbers Tled715-2, Tled715-3, Tled715-6, Tled715-7, Tled715-9. Paratypes: 15 우, body length up to $3.7 \mathrm{~mm}$ ), dive PL166, Port-Miou karstic aquifer, 10-100 m upstream from the dam at a range of 15-23 m depth, Port-Miou, France, coll. P. Chevaldonné, 23 August 2003, 3 in RMNH.CRUS.G.129 (former SME Tled166-1 to 166-3) and 12 in SME, collection numbers Tled166-4 to Tled166-15.

Other material: One incomplete $q$, Port-Miou karstic aquifer, ca. $330 \mathrm{~m}$ upstream from the dam, depth $30 \mathrm{~m}$, Port-Miou, France, coll. M. Douchet, 8(?) June 1993, RMNH.CRUS.G.130. Two specimens (1 incomplete), dive PL163, Port-Miou karstic aquifer, 10-20 m upstream from the dam at a range of 15-17 m depth, Port-Miou, France, coll. P. Chevaldonné, 19 August 2003, SME collection numbers Tled163-1 and Tled163-2.

Description.- Body length (antennae 1 and 2 excluded) of male up to $3.4 \mathrm{~mm}$ (holotype $2.7 \mathrm{~mm}$ ), of female up to 3.7. $\mathrm{mm}$ in the material studied (for habitus see figs. 2-3).

Antenna 1: peduncular segments 1 to 3 with 5, 4 and 2 long plumose macrosetae on respective medial margins; main flagellum 10-11 segmented, last segment with three simple setae of unequal length (sub)terminally; accessory flagellum 5-segmented, last segment with three simple macrosetae of unequal length (sub)terminally.

Antenna 2: peduncular segments 4 and 5 with four teasel macrosetae on medial and mediodorsal margins; flagellum 4-segmented, last segment with three simple macrosetae of 
unequal length (sub)terminally.

Mouthparts: see figs. 4-7.

Labrum: without peculiarities.

Mandible: eight plumidenticulate macrosetae on third segment of palp (fig. 6).

Labium: without peculiarities.

Maxilla 1: endopodite forming a "3"-segmented palp (figs. 4-5), distal margin of basal segment obscurely demarcated from second segment, 1 large unisetulate macroseta on second segment with two rows of seven and one setules (left maxilla 1) and two rows of eight and two setules (right maxilla 1), third segment with one (unisetulate) macroseta with two rows of tiny serrations of which five stronger developed serrations instead of setules.

Maxilla 2 (fig. 7): basipodal endite 1 with eight plumidenticulate macrosetae; basipodal endite 2 with 16 rake-like serrate macrosetae at terminal margin, and 1 modified longer rakelike serrate subterminal macroseta; basipodal endite 3 with six more strongly barbed rake-like macrosetae, which increase in size towards lateral margin of appendage, arranged in two rows of three and three macrosetae, respectively; exopodite 2-segmented, bearing four simple macrosetae.

Maxilliped (figs. 8-10): first segment of male endopodite without club microsetae, second segment with two goups of four and five club microsetae, third segment with 3 patches of club microsetae arranged in groups of four, five and five club microsetae, respectively, fourth segment without club microsetae; basipodal endite bearing 14 plumidenticulate macrosetae with long setules, one medially, eight terminally, four smaller, but taller ones subterminally, one sublaterally, and with an additional stouter plumidenticulate macroseta implanted submedially; exopodite 2-segmented, distal segment with two terminal, one subterminal and one lateral plumose macrosetae.

Gnathopod: baso-ischium of endopodite with indistinctly demarcated "free" ischium, 
propodus with two finely serrate macrosetae on distal half, and dactylus with two unequal, finely serrate macrosetae on ventral margin; exopodite with three medial, two subterminal, two terminal and two lateral plumose macrosetae.

Pereiopods: see figs. 11-13.

Pereiopod 2 (fig. 13): propodus of endopodite with two teasel macrosetae medially on ventral margin, male with 9-10 and female with 15 ovate microsetae, dactylus with two teasel macrosetae on ventral margin and two rows of five and four ovate microsetae in the male holotype and two rows of seven and four ovate microsetae in the females dissected, respectively; first segment of exopodite with four ovate microsetae, second segment with three medial, two subterminal, two terminal and two lateral plumose macrosetae.

Pereiopod 3 (fig. 11): carpus of endopodite with one ovate microseta mediodorsally implanted, propodus of endopodite with two teasel macrosetae on ventral margin, male with 10 and female with 15 ovate microsetae, dactylus with two teasel macrosetae on ventral margin and both male and female with two rows of seven and four (or eight and three in one pereiopod of a female) ovate microsetae, respectively; first segment of exopodite with four ovate microsetae, second segment with three medial, two subterminal, two terminal and two lateral plumose macrosetae.

Pereiopod 4: carpus of endopodite with one ovate microseta mediodorsally implanted, propodus of endopodite with two teasel macrosetae on ventral margin, male with 12 and female with 16-17 ovate microsetae, dactylus with two teasel macrosetae on ventral margin and two rows of seven and four ovate microsetae; first segment of exopodite with three ovate microsetae, second segment with three medial, two subterminal, two terminal and two lateral plumose macrosetae.

Pereiopod 5: ischiomerus of endopodite with one ovate microseta, carpus with one ovate microseta mediodorsally implanted, propodus of endopodite with two teasel macrosetae on 
ventral margin, male with 14 and female with 18-20 ovate microsetae, dactylus with two teasel macrosetae on ventral margin and two rows of seven and four (or six and two in one pereiopod of a female) ovate microsetae; first segment of exopodite with three to four ovate microsetae, second segment with two medial, two subterminal, two terminal and one lateral plumose macrosetae.

Pereiopod 6 (fig. 12): carpus of endopodite with one ovate microseta mediodorsally implanted, propodus of endopodite with one teasel macroseta on ventral margin, male with 17 and female with 20-22 ovate microsetae, dactylus with one teasel macroseta on ventral margin and two rows of five and two ovate microsetae in the male holotype and two rows of seven and two to three ovate microsetae in the females dissected; exopodite 1-segmented with five to six ovate microsetae, one medial and one subterminal plumose macrosetae, two vestigial macrosetae of which one terminal and one laterally implanted.

Pereiopod 7: carpus of endopodite without ovate microseta, propodus of endopodite with one teasel macroseta on ventral margin, male with 17-18 and female with 19-22 ovate microsetae, dactylus with one teasel macroseta on ventral margin and both male and female with two rows of five and two ovate microsetae; exopodite 1-segmented with four ovate microsetae, one medial and one subterminal plumose macroseta, two vestigial macrosetae of which one terminal and one laterally implanted.

First pleopod with six dorsal subplumose macrosetae. Second pleopod with three dorsal, one terminal and one subterminal subplumose macrosetae.

Uropod (fig. 14): segment 1 of exopodite slightly longer than segment 2, segment 1 with lateral armature of one cuspidate macroseta and two plumose macrosetae, medial armature of four stout plumose macrosetae, distalmost accompanied by one small subplumose macroseta; segment 2 with 16 plumose macrosetae in male holotype, 16-20 in the females studied; endopodite bearing 14 to 16 plumose macrosetae. 
Telson (fig. 15) slightly wider than long, mean width/length ratio 0.986-0.99; anal lobes not protruding beyond terminal stretch; stretch concave with distinct central protuberance flanked at either side by one simple glandular macroseta.

Variability.- In general morphology there is not much variation in the animals, although a slight variability was noted in the width/length ratio of the telson. Despite sexual dimorphism between males and females in the number of ovate microsetae on the pereiopods, we established also some variation in the number of ovate microsetae between the two corresponding legs of the same individual. Also, in smaller specimens that number can vary as we noticed, which is rather a result of the length of the segment of the pereiopod available for ovate microsetae. As the smallest male $(2.7 \mathrm{~mm})$ was chosen for dissection, because almost all of its appendages were complete, we do not exclude a small rise in number of ovate microsetae when larger male specimens will be studied in the future. Due to their small size, there are no scars left on the cuticle where the ovate microsetae are broken off. We suspect the ovate microsetae to play a mechanoreceptorial role, comparable to the side line organs in amphipods as discovered by Platvoet (1985).

Etymology. - The name of the new species is dedicated to Dr. Michel Ledoyer, who was the first to make a specimen of this new species available to the senior author for study, 26 years ago, and who was an inspiration to the junior author in advancing the study of marine cave malacostracans. The name thus is a noun in the genitive singular.

Remarks. - Within the "T. argentarii species-group", T. ledoyeri n. sp. can be instantly distinguished morphologically from T. scabra (Pretus, 1991) and T. siracusae Wagner, 1994, by the absence of a scutellated body and having nine plumose macrosetae on the exopodites of pereiopods 2 to 4 rather than eight in T. scabra and T. siracusae. However, although the presence of scutellated bodies is convenient to distinguish these latter species, this distinction 
is not supported by the molecular analysis, which finds $T$. ledoyeri equally distant from $T$. scabra and T. argentarii (Stella, 1951) as can be seen in our phylogenetic analysis (see further below).

The new species resembles most both T. argentarii and T. halophila (S. L. Karaman, 1953). It can be distinguished from T. argentarii by the number and arrangement of the ovate microsetae on the propodus and dactylus of the pereiopods, but also by mouthpart morphology, the setation of pleopod 2, uropods and telson. Typical for T. ledoyeri $\mathrm{n}$. sp. is the slightly developed unisetulate macroseta at the distal portion of the palp (endopodite) of maxilla 1 , which has five strong serrations compared to three setulettes in the female of $T$. aiakos Wagner, 1994 and none in T. argentarii, T. halophila and the male of T. aiakos. Also the second "row" of one or two setulettes on the unisetulate macroseta of the second segment of the left and right maxilla 1 respectively, is a unique character for T. ledoyeri $\mathrm{n}$. sp. In the endopodite of the maxilliped of the males, there is a distinct difference in the pattern and number of patches of club microsetae present in T. ledoyeri n. sp. compared to its congeners. Contrary to the congeners of its species-group that have five, it has six subplumose macrosetae on pleopod 2, a feature that proved constant in all specimens examined. The setation of the uropods is in general less abundant in T. ledoyeri n. sp. than in T. argentarii and T. halophila, a feature which the new species shares with the second segment of the exopod of T. aiakos. The telson of T. ledoyeri n. sp. can be distinguished in morphology from those of $T$. argentarii and $T$. halophila by having three distinct protuberances along the terminal stretch of the telson, resembling that of T. aiakos. A width/length ratio of 0.986 to 0.99 is found, which is close to T. argentarii (0.98), but clearly distinct from T. halophila (0.92) and T. aiakos (0.96). Table I features the salient differences among the species of the $T$. argentarii species-group in more details.

Habitat and ecology.- The water in which this species lives is mixohaline (salinity up 
to $11 \mathrm{~g} \mathrm{~L}^{-1}$ ) with a temperature about constant around $16^{\circ} \mathrm{C}$ year-round. The species is primarily benthic, but will swim around close above the bottom when approached by divers. It is likely feeding on small organic particles (mostly bacteria) in and on the bottom surface. Until very recently, no ovigerous females (with the typical brood pouches) were encountered in any samples examined, so the period of reproduction could not be established. The senior author examined from its closest congeners only ovigerous specimens of $T$. halophila that were captured in July up to 8 August. He also examined ovigerous females of T. scabra that were collected in December, but not in the months January, May, June, or August. If July and December would be the normal breeding-season for the European species, observations of finding ovigerous females in Port-Miou in July (and December) could demonstrate that the sampling sites are indeed part of the natural habitat of T. ledoyeri n. sp., as it then would prove to reproduce there, too. On 21 June 2020, speleo-diver Isabelle Simonnet brought back to us two large live females of T. ledoyeri $(3.8$ and $3.9 \mathrm{~mm})$ captured at the same station the species was discovered in 1993 (fig. 1; $320 \mathrm{~m}$ from the dam, $20 \mathrm{~m}$ depth, salinity 8g/L). Both females appeared to display eggs in their ovaries (fig. 16). Though it was still too early for the females to have brood pouches, it seems that the July period is indeed at least one of the breeding seasons for the new species. Furthermore, as the animals use the area as feeding ground and are regularly seen during biological expeditions, it is most likely that this part of the aquifer is a natural habitat for these creatures. It must, however, be noted that on a total of 6 dives conducted by the junior author at the sampling site, T. ledoyeri n. sp. could not be observed despite intensive search during 3 dives in April 2019. Also, the 1993 specimen was captured in June, while a search in March 1994 produced no results (see above). Most of our material was collected when the species was seemingly abundant in August 2003 and October 2019. The October 2019 dive took place just before the first significant rain event of the season. Such a seasonal abundance pattern has been observed for Tethysbaena sp. near 
Valencia, Spain, where abundance peaks at the end of summer and the beginning of autumn (F. Palero, pers. comm.).

The only other living species observed to co-occur with T. ledoyeri n. sp. is a new, yet undescribed, species of the subterranean amphipod genus Niphargus, which is less abundant than T. ledoyeri n. sp., but seemingly present all the time, at least from April to October, at the sampling site (Chevaldonné et al., 2005; V. Iannilli \& P. Chevaldonné, work in progress). The amphipod is actively preying on T. ledoyeri n. sp. if given the opportunity (e.g., putting them in the same aquarium), as could be seen from bitten-off uropods in the latter (fig. 3, above). Finally, a single, damaged, unidentified copepod ecdysium was also recovered from one sample, testifying a possibly more diverse fauna than, until now, visible to the diver. 
TABLE I

Salient differences between the species of the "Tethysbaena argentarii" species-group.

\begin{tabular}{|c|c|c|c|c|c|c|}
\hline & $\begin{array}{l}\text { T. argentarii } \\
\text { (Stella, 1951) }\end{array}$ & $\begin{array}{l}\text { T. halophila } \\
\text { (Karaman, 1953) }\end{array}$ & $\begin{array}{l}\text { T. aiakos } \\
\text { Wagner,1994 }\end{array}$ & $\begin{array}{l}\text { T. scabra } \\
\text { (Pretus, 1991) }\end{array}$ & $\begin{array}{l}\text { T._siracusae } \\
\text { Wagner, } 1994\end{array}$ & $\begin{array}{l}\text { T. ledoyeri } \\
\text { n. sp. }\end{array}$ \\
\hline \multicolumn{7}{|l|}{ Body: } \\
\hline Bodylength (in mm) & $\mathrm{m}: 2 ; \mathrm{f}: 3.4$ & $\mathrm{~m}: 3 ; \mathrm{f}: 3.7$ & $\mathrm{~m}: 2.8 ; \mathrm{f}: 3.4$ & $\mathrm{m:} 3 ; \mathrm{f}: 3.2$ & m: ?; f: 3.4 & $\mathrm{~m}: 3.4 ; \mathrm{f:} 3.7$ \\
\hline $\begin{array}{l}\text { Scutellated scales } \\
\text { Antenna 1: }\end{array}$ & Absent & Absent & Absent & Present & Present & Absent \\
\hline No. of segm. main flagellum 3 & 10 & 9 & $11-12(+)$ & 10 & 8 & $10-11$ \\
\hline $\begin{array}{l}\text { No. of plumose m.s. segm. 1, 2, } 3 \\
\text { Mandible: }\end{array}$ & $5,5,2$ & $4,5,3$ & $5,5,2$ & $5,5,2$ & 5,6 , unknown & $\mathrm{m}: 5,4,2 \mathrm{f}: 6,5,2$ \\
\hline $\begin{array}{l}\text { No. of plumidenticulate m.s. segm. } 2 \\
\text { Maxilla 1: }\end{array}$ & 9 & 8 & 7 & 7 & 8 & 8 \\
\hline No. of setules uniset. m.s. end. segm. 2 & $10-11$ & $7-8$ & $7-9$ & 10 & $6-8$ & $7+1(1) ; 7+2(r)$ \\
\hline Uniset.m.s. segm. 3 & m\&f: obscure & m\&f: obscure & m: obscure;f: dev. & m\&f: obscure & m: unknown; f: dev. & m\&f: obscure \\
\hline $\begin{array}{l}\text { No. of uniset. m.s. segm. } 3 \\
\text { Maxilla 2: }\end{array}$ & 0 & 0 & $\mathrm{~m}: 0 ; \mathrm{f}: 3$ & 0 & 4 & 0 \\
\hline No. of plumidenticulate m.s. b.e. 1 & 6 & 7 & 6 & 7 & 7 & 8 \\
\hline No. of rake-like m.s. b.e. 2 & $16-17$ & 17 & $15-16$ & 17 & 15 & 17 \\
\hline $\begin{array}{l}\text { No. of rake-like m.s. b.e. } 3 \\
\text { Maxilliped: }\end{array}$ & 6 & 5 & 6 & 6 & 6 & 6 \\
\hline Total No. of terminal plumidenticulate m.s. & $13-15$ & 14 & 14 & $14-18$ & 14 & 14 \\
\hline No. of plumose m.s. ex. & 5 & 5 & 6 & 5 & Unknown & 4 \\
\hline $\begin{array}{l}\text { No. of patches segm. } 2,3 \text { end. male } \\
\text { Gnathopod: }\end{array}$ & 7,7 & 6,6 & 4,4 & 2,4 & Unknown & 2,3 \\
\hline $\begin{array}{l}\text { Demarcation ischium } \\
\text { Pereiopod 2: }\end{array}$ & Obscure & Indistinct & Indistinct & Indistinct & Indistinct & Indistinct \\
\hline No. of ovate microsetae carpus & 0 & 0 & 0 & 1 & 0 & 1 \\
\hline No. of ovate microsetae propodus & m: $13 ; \mathrm{f}: 14$ & $\mathrm{~m}: 12 ; \mathrm{f}: 13$ & $\mathrm{~m}: 13 ; \mathrm{f}: 10$ & m: $11 ; f: 15$ & $\mathrm{f}: 12$ & m: 9-10; f: 15 \\
\hline No. of ovate microsetae dactylus & $10+3$ & $5+2$ & $5+4$ & $6+2+8$ & $5+7$ & $\mathrm{~m}: 5+4 ; \mathrm{f}: 7+4$ \\
\hline No. of ovate microsetae exopodite & 0 & 2 & 0 & 1 & 0 & 4 \\
\hline $\begin{array}{l}\text { No. of plumose m.s. exopodite } \\
\text { Pereiopod 3: }\end{array}$ & 9 & 9 & 9 & 8 & 8 & 9 \\
\hline No. of ovate microsetae carpus & 0 & 0 & 1 & 1 & 0 & 1 \\
\hline No. of ovate microsetae propodus & $\mathrm{m}: 13 ; \mathrm{f}: 16$ & m: 12-13; f: 14 & $\mathrm{~m}: 14 ; \mathrm{f}: 11-12$ & $\mathrm{m:} 11 ; \mathrm{f}: 15$ & $\mathrm{f:} 12-13$ & $\mathrm{~m}: 10 ; \mathrm{f}: 15$ \\
\hline No. of ovate microsetae dactylus & $9+3$ & $5+2$ & $5+4$ & $6+2$ & $5+7$ & $\mathrm{~m}: 5+4 ; \mathrm{f}: 7+4$ \\
\hline No. of ovate microsetae exopodite & 3 & 3 & 5 & 5 & 1 & 4 \\
\hline
\end{tabular}


No. of plumose m.s. exopodite Pereiopod 4:

No. of ovate microsetae carpus

No. of ovate microsetae propodus

No. of ovate microsetae dactylus

No. of ovate microsetae exopodite

No. of plumose m.s. exopodite

Pereiopod 5:

No. of ovate microsetae ischiomerus

No. of ovate microsetae carpus

No. of ovate microsetae propodus

No. of ovate microsetae dactylus

No. of ovate microsetae exopodite

No. of plumose m.s. exopodite

Pereiopod 6:

No. of ovate microsetae ischiomerus

No. of ovate microsetae carpus

No. of ovate microsetae propodus

No. of ovate microsetae dactylus

No. of ovate microsetae exopodite

No. of plumose m.s. exopodite

Pereiopod 7:

No. of ovate microsetae ischiomerus

No. of ovate microsetae carpus

No. of ovate microsetae propodus

No. of ovate microsetae dactylus

No. of ovate microsetae exopodite

No. of plumose m.s. exopodite

Pleopod 2:

No. of dorsolateral subplumose m.s.

Uropod:

No. of plumose m.s. segm. 2 ex.

No. of plumose m.s.

Telson:

Mean width/length ratio
9

m: 13-14; f: 17

$8+3$

9

0

$14-15 ; \mathrm{f:} 21$

5

8

1

0

m: 16; f: 21

7

$2+2$ vest.

$\begin{array}{ll}1 & 0 \\ 0 & 0 \\ \text { m: } 17 ; \text { f: } 22-23 & \text { m: } 18 ; f: 24 \\ 6 & 5+2 \\ 3 & 3 \\ 2+1 \text { vest. } & 2+2 \text { vest. }\end{array}$

20-22

11-16

0.98 m: 13-15; f: $16-17$ $5+2$

5

m: 15-16; f: 20

$5+2$

5
8

1

m: 16; f: 21-22

$5+2$

$2+2$ vest.

0

19-22

19-21

0.92 m: 14-15; f: 13-14 $5+4$

0

m: $15-16$; f: 15

$5+4$

4
$7-8$

1

m: 19-20; f: 15

$5+4$

$2+2$ vest.

1

1

m: 21-22; f: 16-17

$5+4$

$2+1$ vest.

16-17

$17-23$

0.96
6 (juv.)

f: 15

$7+2$

5

6 (juv.)

: 12; f: 16-17

$7+3$

m: 15-16; f: 15

0

Unknown m: 14; f: 18-20

Unknown $\quad 7+2$

Unknown 3-4

7 (juv.)

$\begin{array}{ll}0 & 0 \\ 0 & 1\end{array}$

f: 17

$7+2$

2

$2+1$ vest. (juv.)

0

f: 19

$7+2$

$6+2$

$2+2$ vest.

$2+1$ vest. (juv.)

14 (juv.)-22 16-20

12 (juv.)-14 14-16

1.00

0

m: 17; f: $20-22$

m: $5+2 ; \mathrm{f}: 7+2-3$

$5-6$

$2+1-2$ vest.

m: 18; f: 19-22

+2 vest.

19-22

$18-25$

0.97

Abbreviations: b.e. = basiopodal endite; dev. = developed; end. = endopodite; ex. = exopodite; $\mathrm{f}=$ female; juv. $=$ juvenile/immature; $1=$ left $; \mathrm{m}=$ male; m.s. = macroseta(e); $r$ = right; segm. = segment; uniset. $=$ unisetulate; vest. $=$ vestigial; No. of $=$ number of ... 


\section{DNA ANALYSIS}

The 1014 bp 18S nuclear DNA sequence obtained for specimen Tled715-1 could be compared with the only two other sequences available in DNA databases for this marker, i.e., one of Tethysbaena argentarii, originating from the type locality at Monte Argentario, Italy, and one of T. scabra, from Mallorca, Spain. Our sequence of T. ledoyeri n. sp. is close to both other sequences and is equally distinct from each of them ( $0.8 \%$ divergence).

The mitochondrial COI sequences obtained for Tled163-1 and Tled 715-1 were of unequal quality, therefore also of unequal length (531 vs. 669 bp, respectively). They could, however, be compared on a 526 bp alignment, that yielded 27 mutations, i.e., ca. 5\% divergence among sequences. Although corresponding to only one non-synonymous mutation (therefore occurrence of pseudogenes is unlikely), it is a rather high level for intra-specific malacostracan COI (see for example Rastorgueff et al., 2014). There is an extensive COI dataset available for comparison in the DNA databases, mostly due to the study by Canovas et al. (2016) that focused on the T. scabra species-complex in the Balearic Islands. The taxa available for comparison are T. argentarii, T. atlantomaroccana (Boutin \& Cals, 1985), several undescribed species from Morocco, Oman and the Dominican Republic, as well as the T. scabra species complex. Available sequences are of unequal length and only 469 bp could be used for comparison with our T. ledoyeri n. sp. sequences. Not surprinsingly, the taxa closest to $T$. ledoyeri $\mathrm{n}$. sp. in that dataset are the two geographically closest Western European species T. argentarii and T. scabra (fig. 17). COI and $18 \mathrm{~S}$ data do not point to a closer relationship between T. ledoyeri n. sp. and T. argentarii, as suggested by their greater morphological similarities (table I). However, the absence of T. halophila and T. siracusae from DNA databases makes it difficult to conclude any further. The other species are at least $18 \%$ divergent, which is close to saturation at this molecular marker. It is difficult to establish the closest relative to T. ledoyeri n. sp., since it is $8-10 \%$ divergent from T. argentarii and 8- 
$10 \%$ divergent from the various T. scabra lineages uncovered by Canovas et al. (2016). From our preliminary phylogenetic reconstruction (fig. 17) we can only say that T. ledoyeri n. sp. forms a clade distinct from the two other species and that it appears to belong to the same species group. Interestingly, the difference between our two T. ledoyeri n. sp. sequences is of the same order as the difference between the cryptic lineages found in T. scabra. The same type of divergence $(5-6 \%)$ is also found between populations of a thermosbaenacean species of the genus Halosbaena from the Western Cape Range, Australia, for geographic distances of ca. $20 \mathrm{~km}$ (Page et al., 2018). Although our molecular dataset is still very restricted and preliminary ( 2 specimens collected with a 16 years interval), we can not discard the possibility that several cryptic lineages also co-exist within the huge karstic system of the Basse Provence.

\section{ACKNOWLEDGEMENTS}

We are most indebted to Dr. Michel Ledoyer (Station Marine d'Endoume, AixMarseille Université, France) for making the first Port-Miou thermosbaenacean caught by Marc Douchet's team available to us for study. M. Ledoyer was thrilled by the further discovery of more specimens in 2003 , and followed the progress of this study with great interest until his death in 2015. Numerous people have helped gathering the specimens studied here. In 1993: Speleo-divers of FFESSM, especially M. Douchet. In 2003: Hydrogeologists T. Cavalera and E. Gili, divers/biologists R. Graille and C. Lejeusne, and the Société des Eaux de Marseille (SEM). In 2019: Speleo-diver F. Swierczynski, diver L. Vanbostal, underwater cameramen J. C. Granjon and F. Launette, documentary team members N. Argillet and J. Izquierdo, The Calanques National Park, G. Aquaviva and the 'Cassis Rivières Mystérieuses' NGO, and the OSU Institut Pytheas Diving Department. DNA sequences were obtained with the help of M. Dubois and the Molecular Biology Lab at SME - IMBE. Finally, I. Simonnet captured the first ovigerous females in 2020. F. Palero is 
acknowledged for very useful talks around thermosbaenaceans, D. Jaume and J. Pons for sharing sequence data. PC's biological interest in the Port-Miou system initiated with M. Debatty, then was raised by inspirational researchers/divers/cavers at the Station Marine d'Endoume (R. Plante, J. G. Harmelin, J. Vacelet, H. Zibrowius, R. Fichez) and by the generation they inspired (A. Iehlé, D. Durand, E. Charbonnel, A. L. Boyer, L. Barillé, C. Dufy).

\section{REFERENCES}

ANONYMOUS, 1978. Le captage de la résurgence sous-marine de la rivière "Port-Miou" près de Cassis. Chantiers de France, 104: 1-8.

ARfiB, B., X. MÉniscus \& F. SWIERCZYNSKI, 2018. Far and deep into the brackish groundwater of coastal karst: crossing CTD time series monitoring in submarine spring and during cave diving exploration (Port-Miou and Bestouan-SE France): 1-3. (EUROKARST 2018, July 2018, Besançon, France).

Canovas, F., J. A. Jurado-Rivera, E. Cerro-Galvez, C. Juan, D. Jaume \& J. Pons, 2016. DNA barcodes, cryptic diversity and phylogeography of a W Mediterranean assemblage of thermosbaenacean crustaceans. Zool. Script., 45: 659-670.

CAVAlera, T., 2007. Etude du fonctionnement et du basin d'alimentation de la source sousmarine de Port-Miou (Cassis, Bouches-du-Rhône). Approche multicritère: 1-403. (Doctoral Thesis, Université de Provence, Marseille, France).

Chevaldonné, P., T. CAVAlERA \& R. GRAILle, 2005. First biological investigations of the Port-Miou karstic aquifer, an underground river with a marine outlet (South France). In: $40^{\text {th }}$ European Marine Biology Symposium, Vienna (Austria), 21-25 August 2005. 
Chevaldonné, P., P. A. Rastorgueff, D. Arslan \& C. Lejeusne, 2015. Molecular and distribution data on the poorly known, elusive, cave mysid Harmelinella mariannae (Crustacea: Mysida). Mar. Ecol., 36: 305-317.

Chevaldonné, P., B. Sket, C. Marschal, C. Lejeusne \& R. CAlado, 2008. Improvements to the "Sket bottle": a simple manual device for sampling small crustaceans from marine caves and other cryptic habitats. J. Crustac. Biol., 28: 185-188.

Corroy, G., C. Gouvernet, J. Chouteau, A. Sivirine, R. Gilet \& J. Picard, 1958. Les résurgences sous-marines de la région de Cassis. La Fontaine de Vaucluse. Résultats scientifiques des explorations de 1955 et 1956. Bull. Instit. Océanogr., 55: 1-35.

FAGe, L. H., 1993. Port-Miou et le Bestouan: doublet record pour les Marseillais. Spéléo, 12: 3-6.

GILlI, E., 2001. Compilation d'anciennes mesures de débit à Port-Miou. Apport à l'hydrogéologie de la Basse Provence. $7^{\text {th }}$ Conference on Limestone Hydrology and Fissured Media, Besançon, 20-22 September 2001.

Guindon, S., J. F. Dufayard, V. Lefort, M. Anisimova, W. HordiJK \& O. Gascuel, 2010. New algorithms and methods to estimate Maximum-Likelihood phylogenies: Assessing the performance of PhyML 3.0. Syst. Biol., 59: 307-321.

HALL, T. A., 1999. BioEdit: a user-friendly biological sequence alignment editor and analysis program for Windows 95/98/NT. Nucleic Acids Symposium Series, 41: 95-98.

JAUME, D., 2008. Global diversity of spelaeogriphaceans \& thermosbaenaceans (Crustacea; Spelaeogriphacea \& Thermosbaenacea) in freshwater. Hydrobiologia, 595: 219-224.

Larkin, M. A., G. Blackshields, N. P. Brown, R. Chenna, P. A. McGettigan, H. McWilliam, F. Valentin, I. M. Wallace, A. Wilm, R. Lopez, J. D. Thompson, T. J. GiBson \& D. G. Higgins, 2007. Clustal W and Clustal X version 2.0. Bioinformatics, 23: $2947-2948$. 
Lefort, V., J. E. Longueville \& O. Gascuel, 2017. SMS: Smart Model Selection in PhyML. Mol. Biol. Evol., 34: 2422-2424.

LOMBARD, G., 1977. Réalisation d'un barrage en galerie immergée à Port-Miou. Cahiers des Comités de Prévention du Bâtiment et des Travaux Publics, 3(77): 1-6.

LOMBARD, G. \& L. Potié, 1980. Fascicule d'information FRANKARST (S.A.R.L.): 1-4. (FRANKARST, Marseille).

MARTIN, C., 1968. La résurgence sous-marine de Port-Miou. Spelunca, (4) 8 (3): 14-20.

MÉNISCUS, X., 2017. Encore plus profond à Port-Miou :-233. Spelunca, (5) 146: 27-29.

Page, T. J., J. M. Hughes, K. M. Real, M. I. Stevens, R. A. King \& W. F. Humphreys, 2018. Allegory of a cave crustacean: systematic and biogeographic reality of Halosbaena (Peracarida: Thermosbaenacea) sought with molecular data at multiple scales. Mar. Biodiv., 48: 1185-1202.

Platvoet, D., 1986. Side-line organ in gammarids (Crustacea, Amphipoda). Beaufortia, 35(7): 129-133.

Potié, L., 1979. Ressources en eau des zones côtières. Captage des résurgences sous-marines littorales. Risques de pollution et protection des aquifères côtiers en milieu fissuré ou karstique. Techniques et Sciences Municipales, 3 (mars 1979): 131-134.

Rastorgueff, P. A., P. Chevaldonné, D. Arslan, C. Verna \& C. Lejeusne, 2014. Cryptic habitats and cryptic diversity: Unexpected patterns of connectivity and phylogeographical breaks in a Mediterranean endemic marine cave mysid. Mol. Ecol., 23: $2825-2843$.

ScHMIT, P., 1993. Moins 147 mètres dans le gouffre de Port-Miou ! Le Provençal, 13 June 1993.

Vernette, J. L., 1968. Port-Miou 1968. Historique. (Unpublished report, 13 pp.)

WAGNeR, H. P., 1994. A monographic review of the Thermosbaenacea (Crustacea: 
Peracarida). A study on their morphology, taxonomy, phylogeny and biogeography.

Zool. Verh., Leiden, 291: 1-338.

First received 27 June 2020.

Final version accepted 8 July 2020. 
Fig. 1. Diagram of the karstic aquifer of Port-Miou and the sampling sites of Tethysbaena ledoyeri n. sp. [Modified after Chevaldonné et al., 2005.]

Fig. 2. Live Tethysbaena ledoyeri n. sp., female in toto, dive PL166. [Photo: P. Chevaldonné / CNRS.]

Fig. 3. Tethysbaena ledoyeri n. sp., female with uropod bitten-off by amphipod, dive PL166. [Photo: P. Chevaldonné / CNRS.]

Figs. 4-7. Tethysbaena ledoyeri n. sp., $\widehat{\jmath}$, holotype: 4, palp of left maxilla 1; 5, palp of right maxilla $1 ; 6$, palp of mandible; 7 , maxilla 2 . Scale bar represents $0.1 \mathrm{~mm}$.

Figs. 8-13. Tethysbaena ledoyeri n. sp., $\widehat{\jmath}$, holotype: 8 , detail of microsetae on distal portion of endopodal segment 2 of maxilliped (scale C); 9, detail of microsetae on distal portion of endopodal segment 3 of maxilliped (scale C); 10, distal portion of basipodal endite of maxilliped (scale B); 11, distal portion of pereiopod 3 (scale A); 12, distal portion of pereiopod 6 (scale A); 13, pleopod 2 (scale B). All scale bars represent $0.1 \mathrm{~mm}$.

Figs. 14-15. Tethysbaena ledoyeri n. sp., Ô, holotype: 14, uropod; 15, telson. Scale bar represents $0.1 \mathrm{~mm}$.

Fig. 16. Live Tethysbaena ledoyeri n. sp., female with eggs, sample IS1-1 from 21 June 2020. [Photo: P. Chevaldonné / CNRS.] 
Fig. 17. Phylogenetic placement of Tethysbaena ledoyeri n. sp. among Tethysbaena taxa available in DNA databases, all from the dataset of Canovas et al. (2016). Neighbour Joining (NJ, shown here) and Maximum Likelihood (ML) reconstruction methods gave a similar topology. Bootstrap (1000 replicates) values higher than 900 are shown at nodes (ML/NJ) in this order. For T. scabra (Pretus, 1991), clade letters correspond to the sampling sites as in Canovas et al. (2016). 


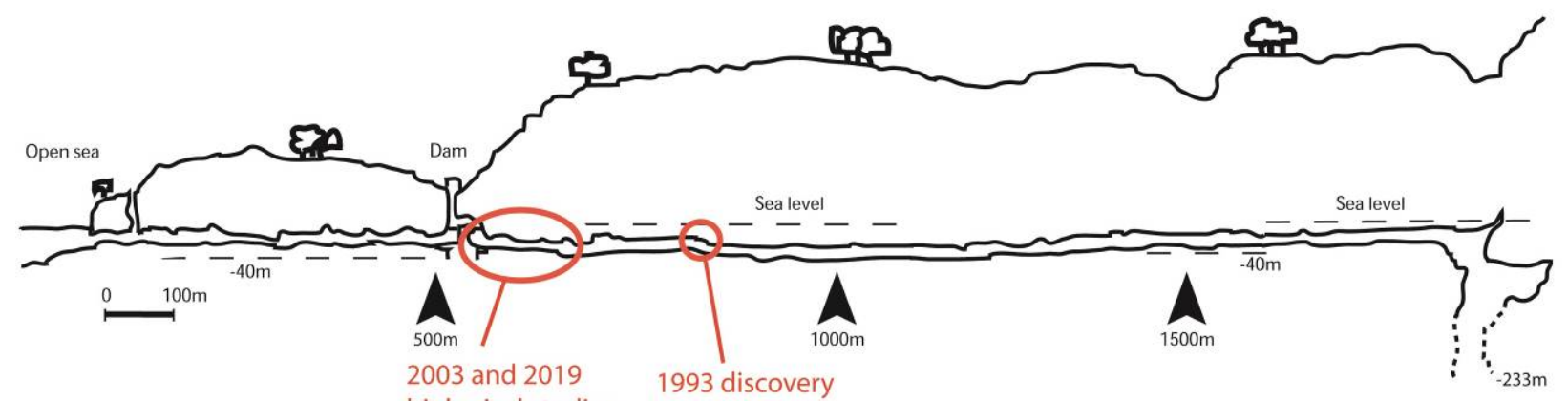

Fig. 1

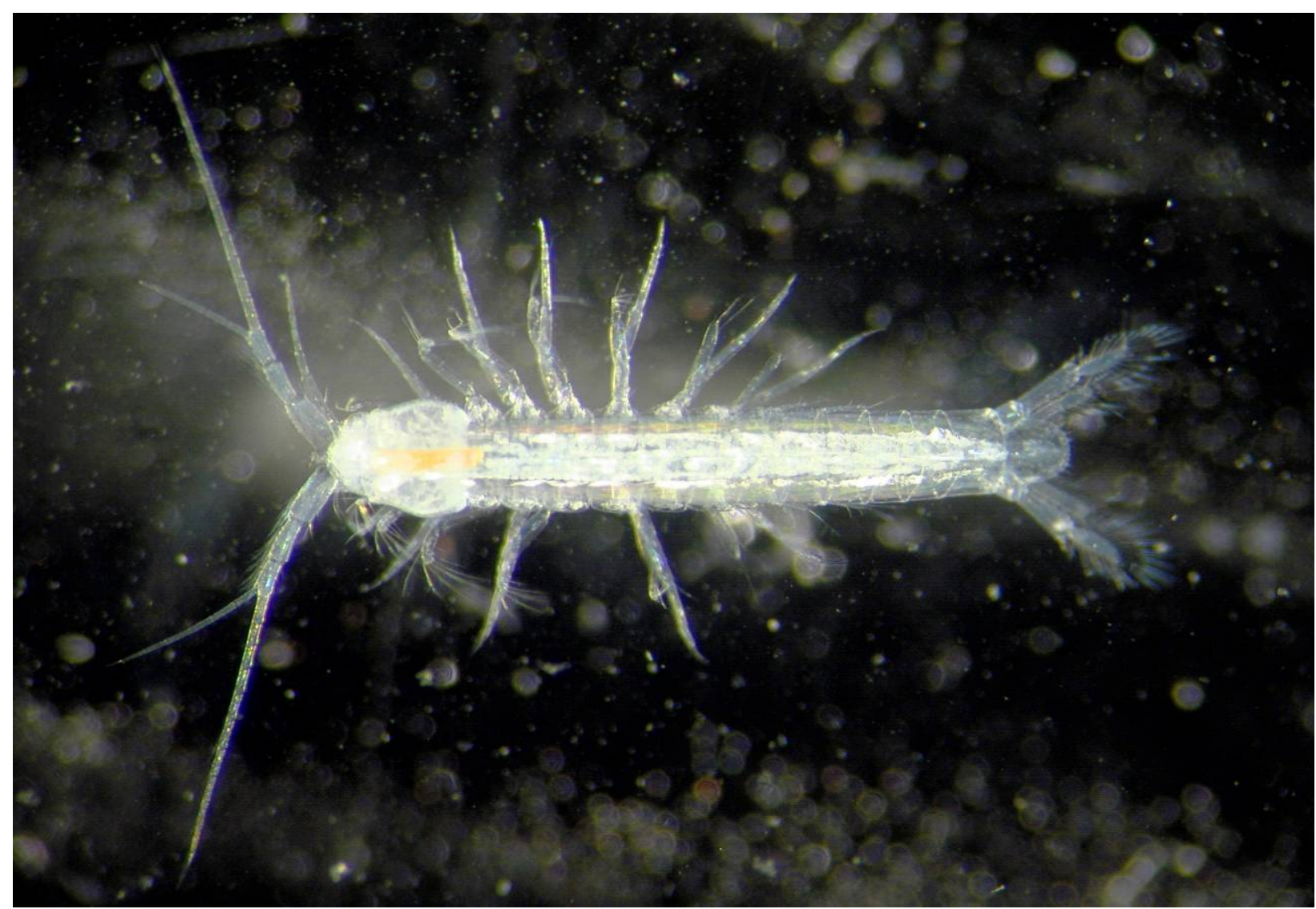

Fig. 2 


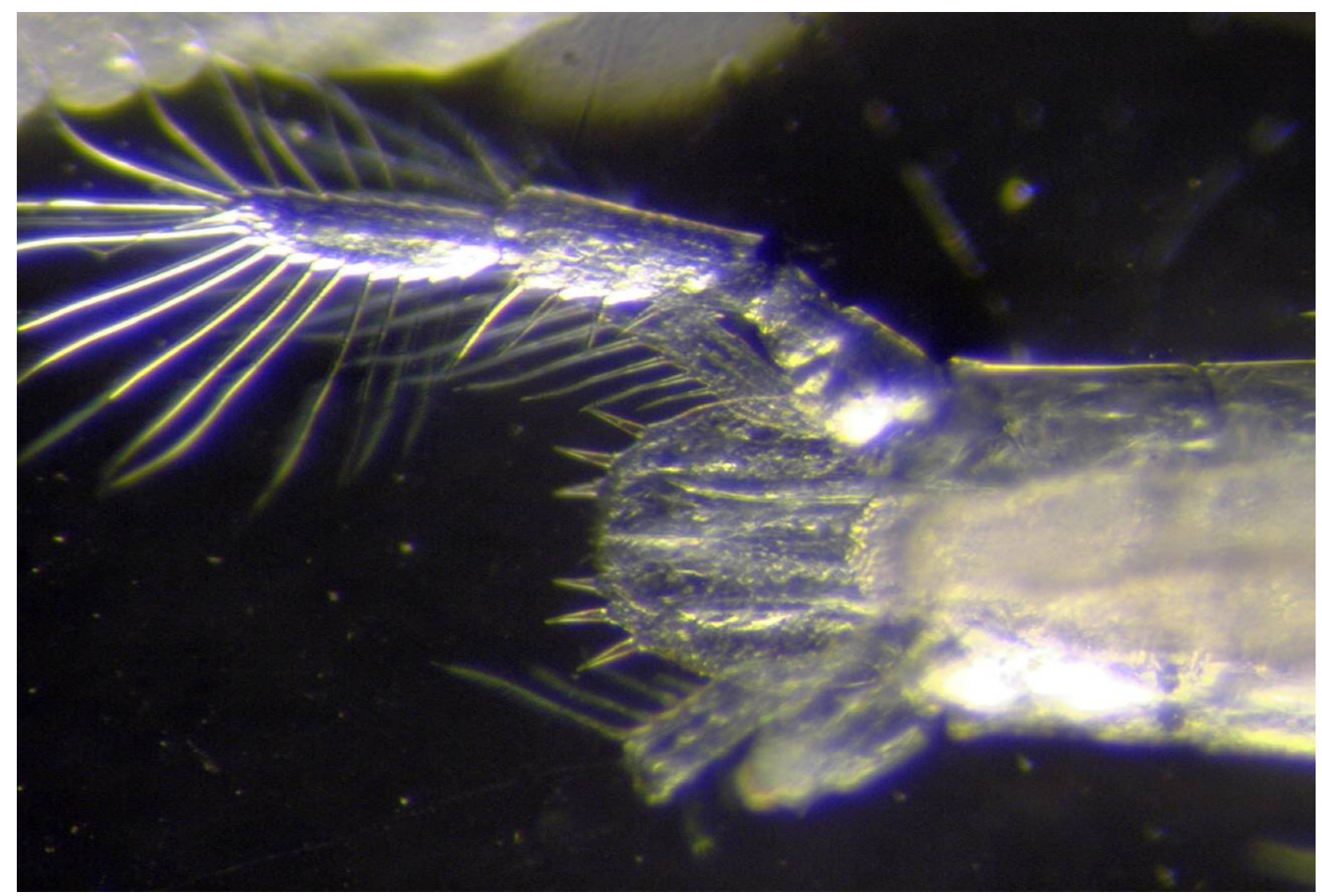

Fig. 3 

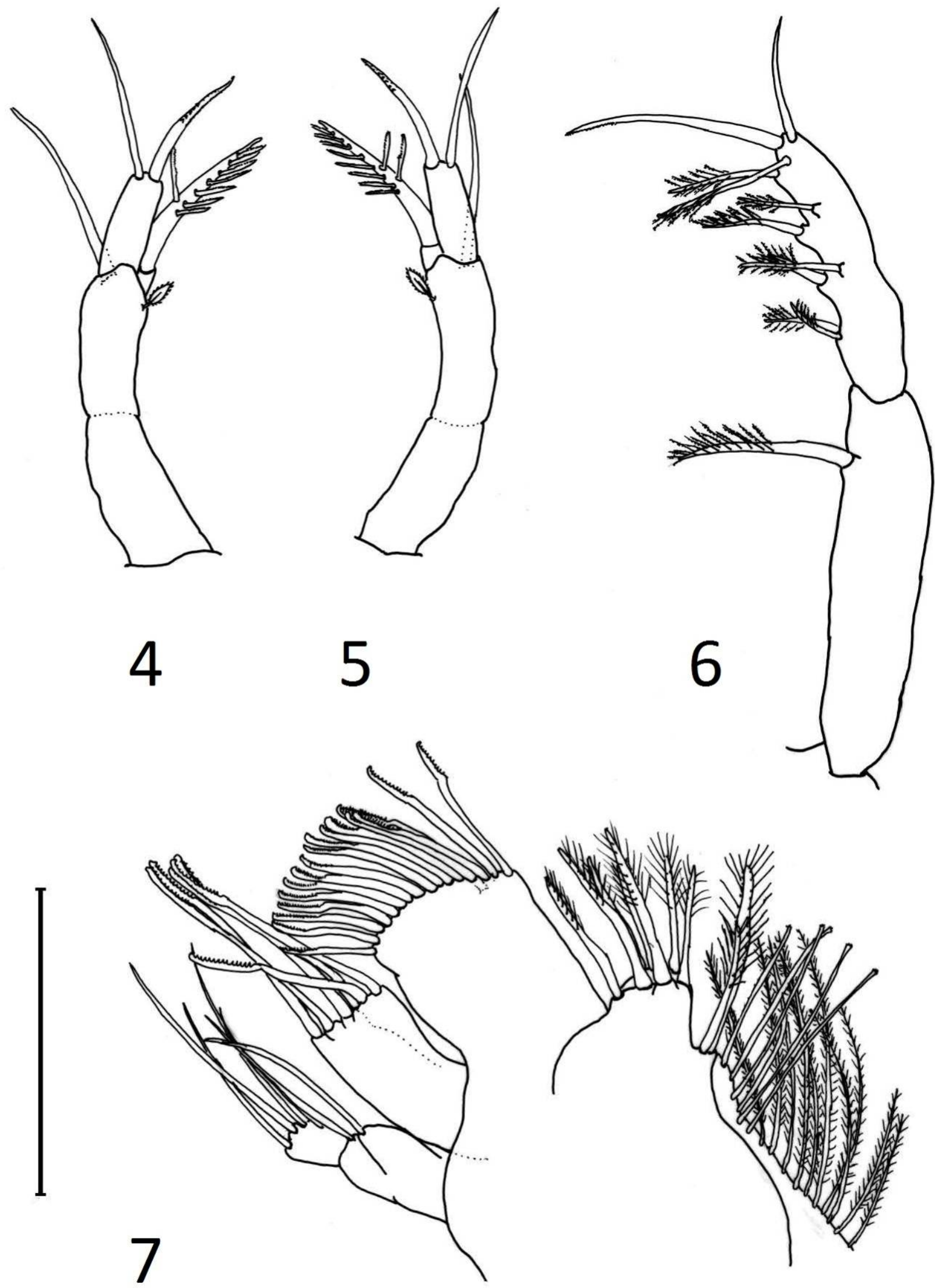

Fig. 4-7 


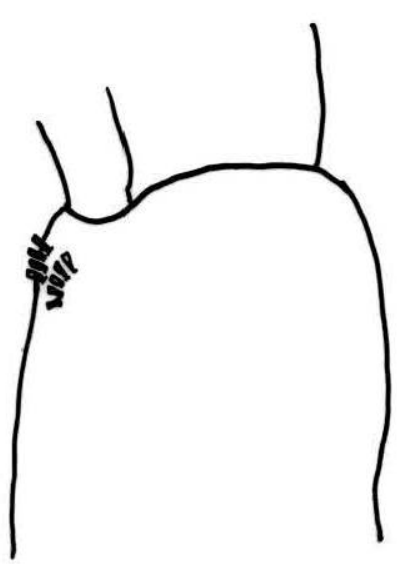

8
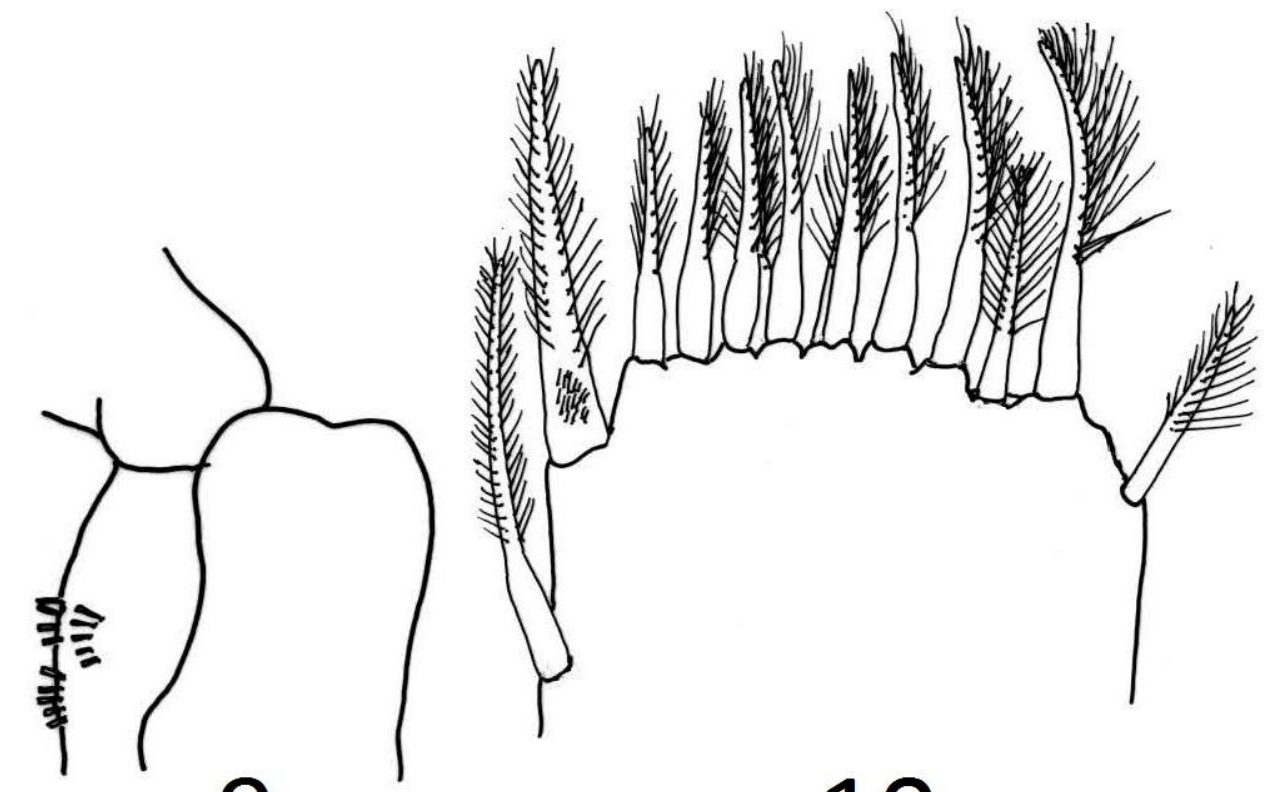

10
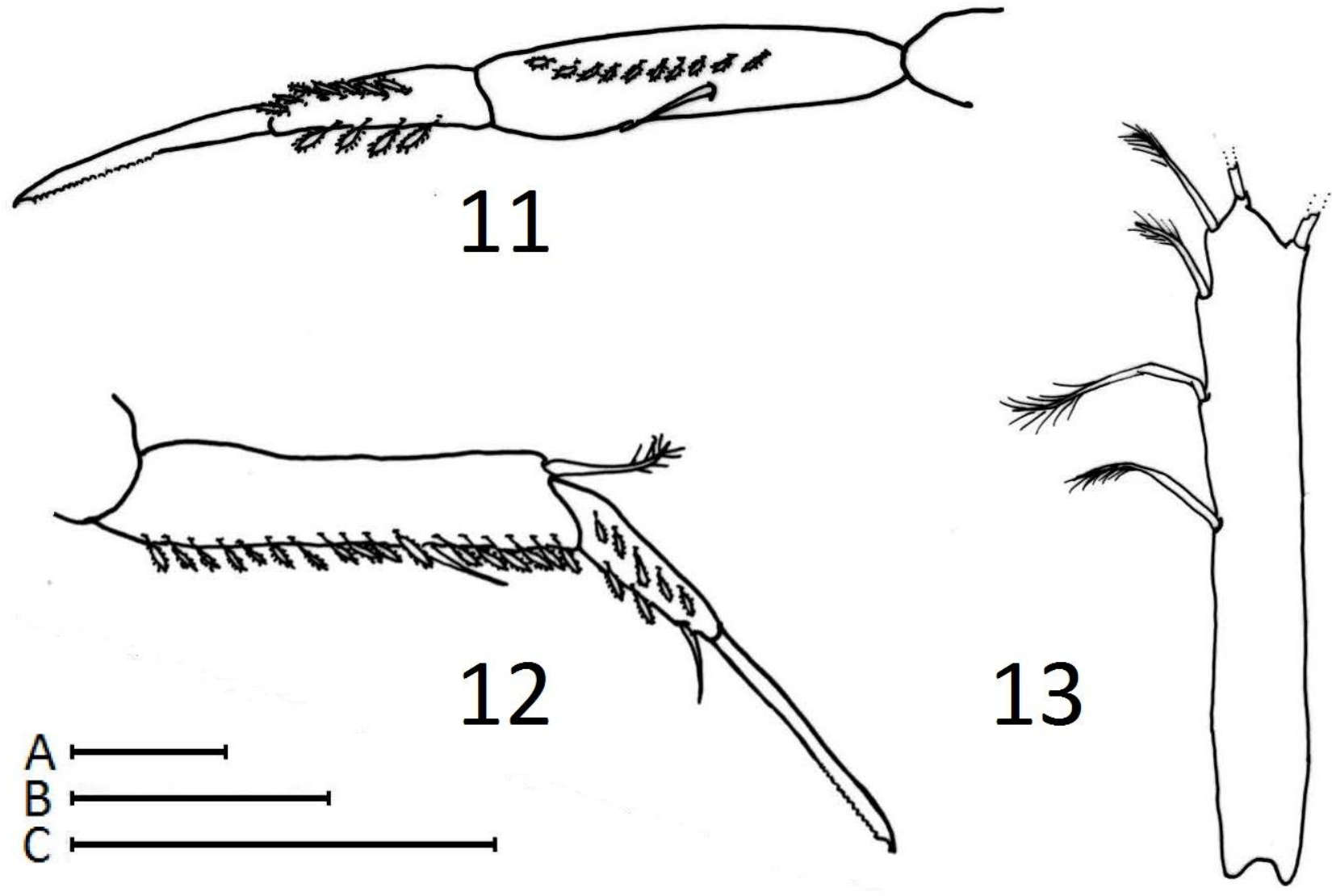

Fig. 8-13 


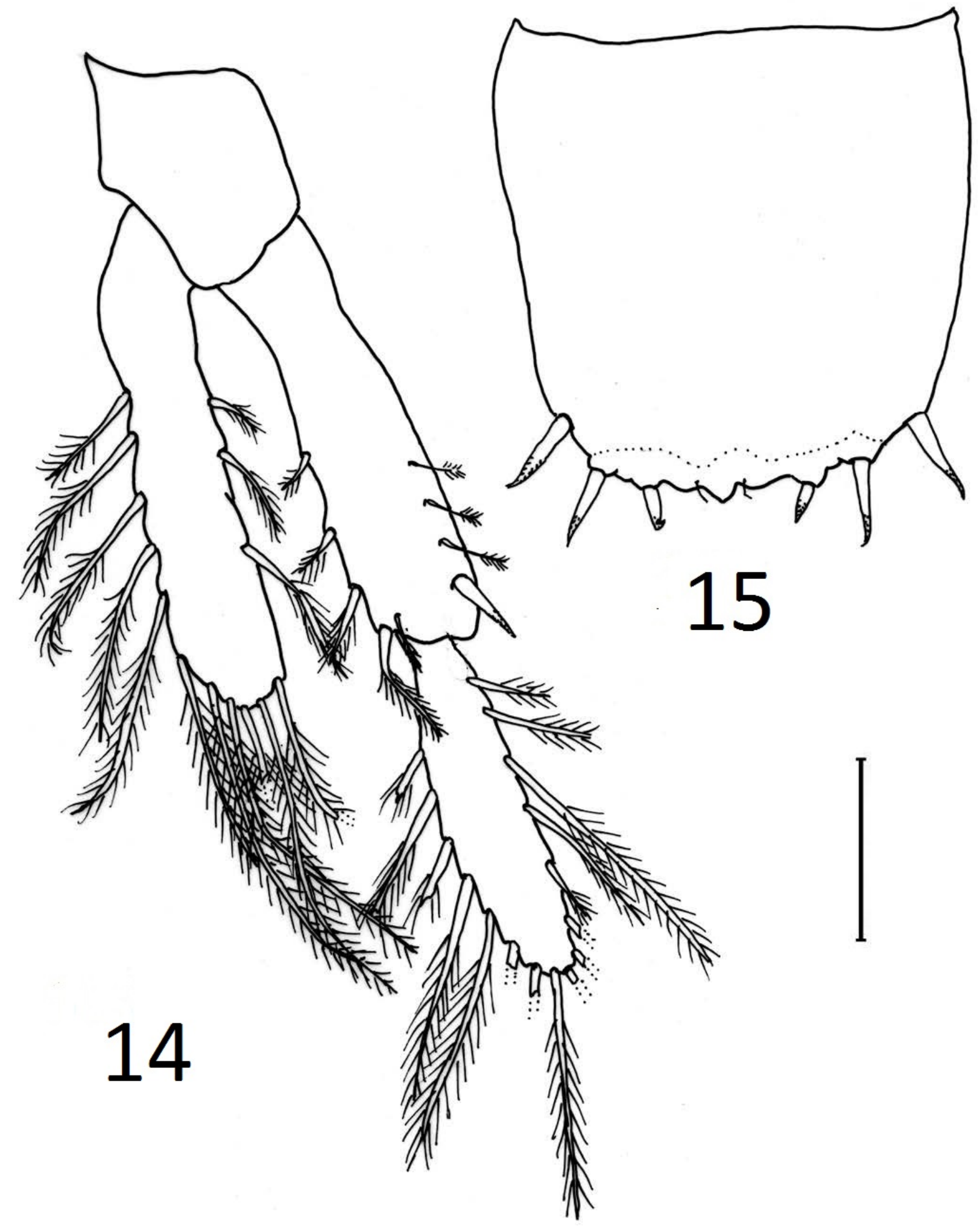

Fig. 14-15 


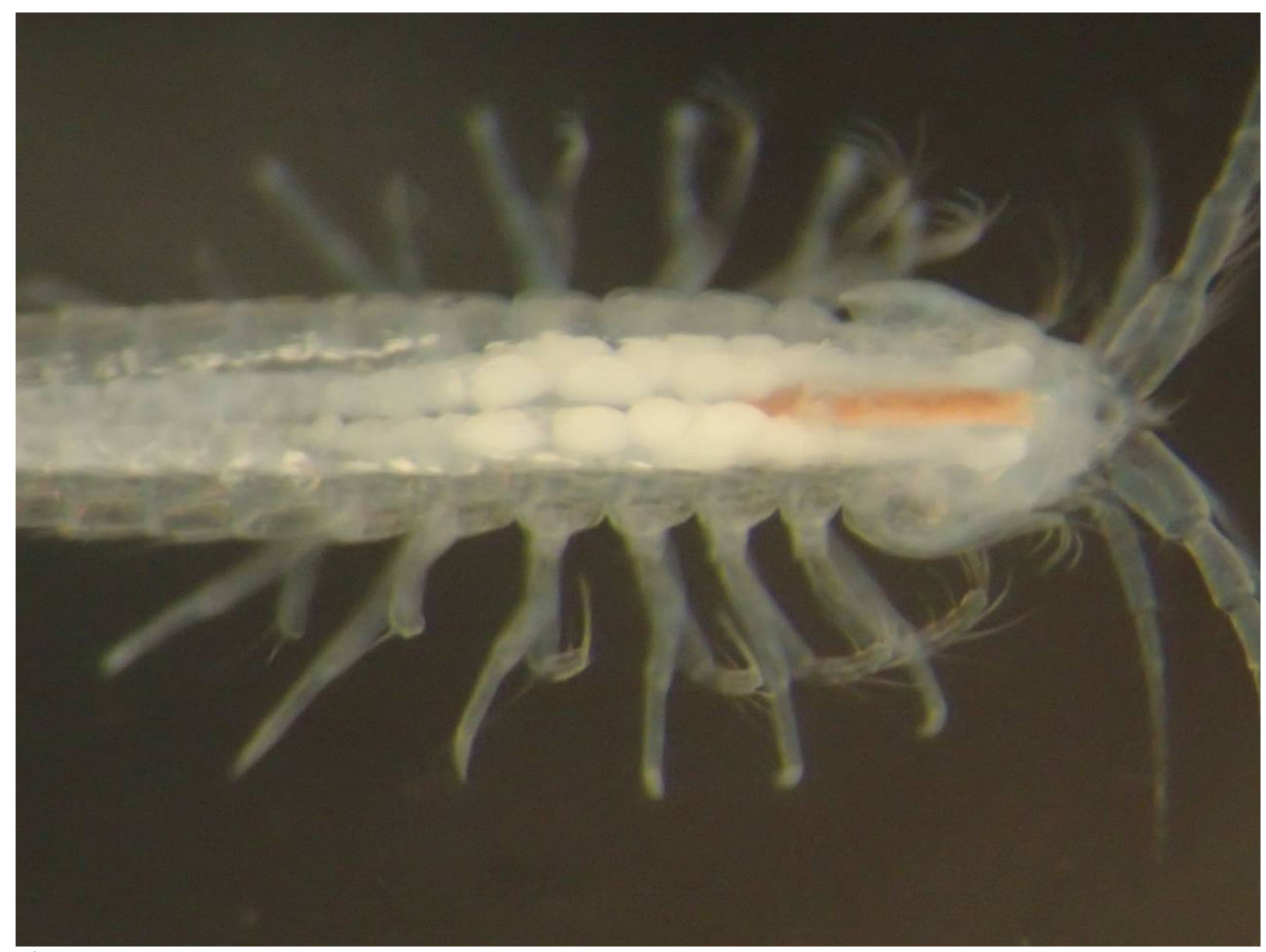

Fig. 16 


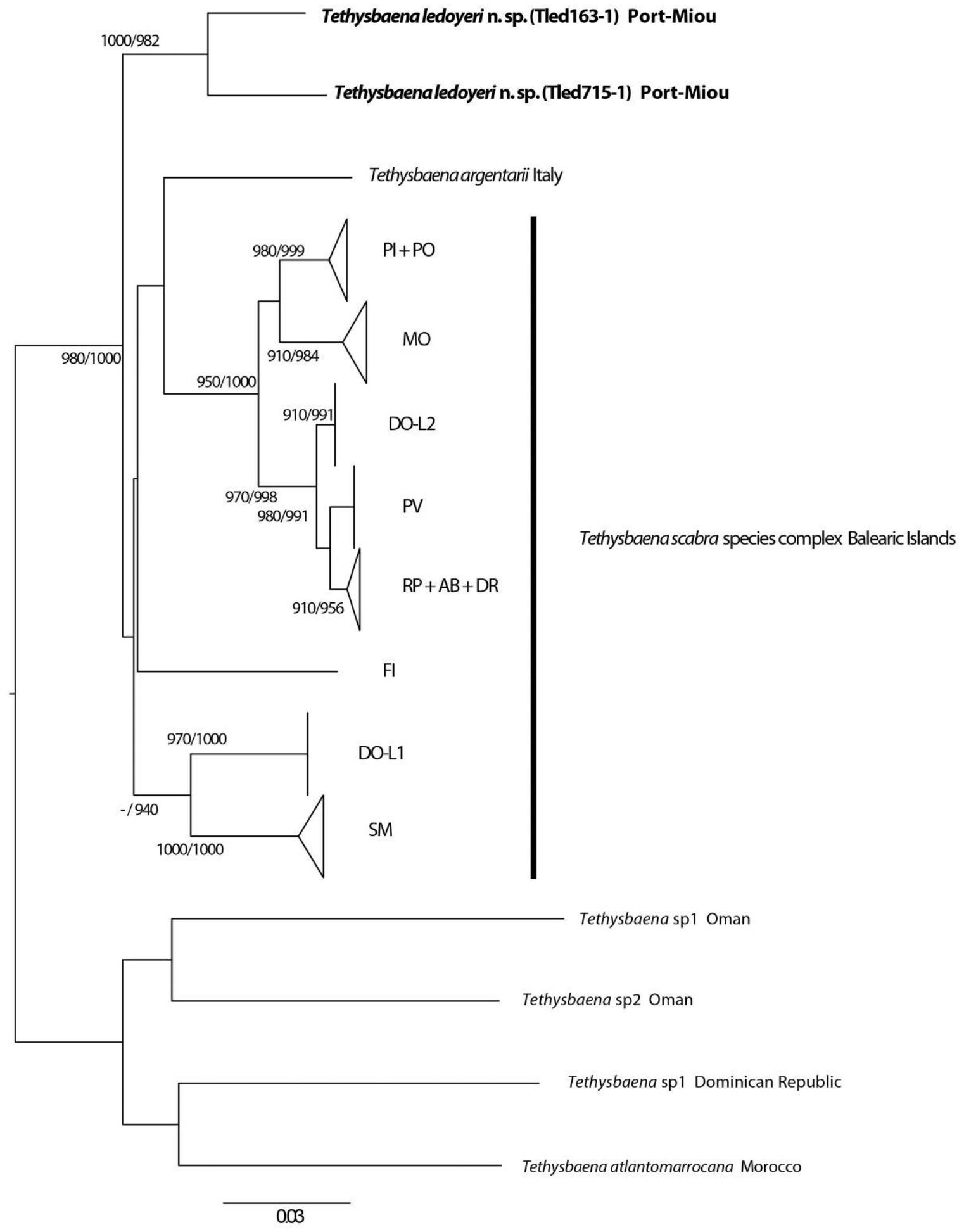

Fig. 17 